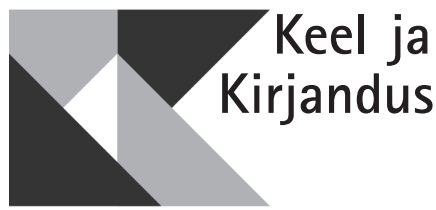

\title{
SPORTLANNA KEHA JA HING JOHANNES SEMPERI NOVELLIKOGUS „ELLINOR”
}

\author{
MERLIN KIRIKAL
}

J

ohannes Semper on eesti kultuurilukku kinnistunud eelkõige luuletaja, kriitiku ja tõlkijana. Proosakirjanikuna on ta aga jäänud tagaplaanile. Oma rolli mängivad selles Semperi poliitilised otsused ning tema hilise proosa - eelkõige sotsialistliku realismi vaimus kirjutatud „Punaste nelkide” (1955) - kaheldav ilukirjanduslik väärtus (Hasselblatt 2016: 479; Olesk 2002: 98). Ent Semper avaldas enne üsna tendentslikku romaani „Kivi kivi peale” (esmailmunud 1939) ja „Punaseid nelke” mitmeid eriilmelisi proosateoseid, mida ei ole üksikasjalikult uuritud, ehkki need vääriksid seda.

Üks omanäolisemaid neist on naisminajutustajaga novellikogu „Ellinor” (1927), millesse kaasaja kriitikud suhtusid nii tunnustavalt (Kärner 1928: 444-445; Sillaots 1928) kui ka jahedalt või lausa hävitavalt (Kivikas 1928a, 1928b). Viiest novellist koosnev „Ellinor” on nii eesti kirjandusloos kui ka Semperi loomingus ainulaadne kogumik kolmel põhjusel. Esiteks on selle läbiv minategelane noor keskklassi eesti naine Ellinor: meesautor on valinud sündmuste vahendajaks naisekuju, ${ }^{1}$ kes on tegutsemisaldis ja ihaldab vabadust. Teiseks on selle kogu keskmes kehalised tegevused ja sport, mis loovad dünaamilist, modernset elutunnet. Seda võib seostada meelelisust, tunnetust, naudinguid ja optimismi esiplaanile seadva nähtusega, mida Semper nimetab oma kirjanduslike eeskujude Emile Verhaereni ja André Gide’i põhjal entusiasmi-

${ }^{1}$ Vastupidiseks näiteks samast ajast on Aino Kallase meesjutustajaga novellid „Barbara von Tisenhusen” (1923, e k 1924), „Reigi õpetaja” (1926, e k 1928) ja „Hundimõrsja” (1928, e k 1929), mis moodustavad triloogia „Surmav Eros”. 
kultuuriks ${ }^{2}$ (Semper 1914, 1929: 35) ning mis on hiljemgi mõjutanud Semperi ilukirjandust ja esseistikat. Kogumikus „Prantsuse vaim” (1934) ütleb ta, et sport on „uus ala, mida eelkäiv põlv veel ei tundnud, mida aga järeltulijad austavad kui uut elutunnet"3 (Semper 1934b: 175). Osalt just sellel uuel elutundel „Ellinor” rajanebki. Kolmandaks on „Ellinor” Eesti kontekstis silmatorkav „uue naise” ning eriti homoseksuaalsuse käsitlemise tõttu, mille kaudu jutustaja dekonstrueerib nii tollaseid traditsioonilisi soorolle kui ka normatiivset seksuaalsust. „Ellinor” on katse luua modernne sportlik ideaalnaine, kellele on antud hääl ning minavormi abil ka valitsev positsioon. ${ }^{4}$

Millist ideoloogiat kannavad (naiste)sport ja (sportlik) naisekeha „Ellinoris"? Semperi soolistatud kehakujutusi analüüsin lähtuvalt nüüdisaegsest kehauurimisest, mille tuumaks on esiteks arusaam, et keha ja mõistus toimivad koos, ning teiseks rõhutus, et enesetaju kujunemise ja subjektsuse analüüsimisel on tarvilik arvesse võtta ka kultuurilisi keharepresentatsioone (Hillman, Maude 2015: 1; Richardson, Locks 2014: ix). Süüvimine naise- ja mehekehade kujutustesse võimaldab mõtestada moderniseerumisega kaasnenud murranguid soosuhetes ning nihkeid hoiakutes ja elustiilis (Hillmann, Maude 2015: 2). Niisiis toetun eeldusele, et kehataju ja -režiimi muutused toovad nähtavale aktuaalsed sotsiaalkultuurilised ja (soo)ideoloogilised teemad (Turner 2012: 5). Lisaks pean Semperi naistegelaste analüüsimisel silmas XX sajandi esimese poole Eesti ja Euroopa ühiskondlikke tõekspidamisi, mida mõjutasid nii naisemantsipatsioon („uue naise” kuju) kui ka sellele vastanduvad antifeministlikud ideed ja nendega põimuv (soolistatud) rahvuslik ideoloogia. Vaatlen, kuidas need tegurid ilmnevad Semperi „Ellinoris”, milles kehad kannavad nii vabastavaid kui ka ühiskondlikule survele alluvaid tähendusi.

Neid tähendusi vahendab „Ellinori” energiline minategelane, kajastades oma muljeid, püüdlusi ja kaastegelaste vaatlemisest tulenevaid arvamusi. Novellide ajaplaan viitab Esimese maailmasõja ja Vene kodusõja aastatele (Karelson 2015: 274). Esimeses novellis „Karikakar” väljendab teismeeas Ellinor soovi elada täisväärtuslikumat elu, vabaneda ühiskondlikest kammitsaist ning armastada. Otseselt on sõjaga seotud teise novelli „Astrid” tegevustik: äsja kooli lõpetanud Ellinor on sattunud kauge sugulase maamajja ning võõrustab ja põetab seal soldateid. Sõjamärgid ilmnevad hiljemgi Ellinori märkustes, mida ta teeb meestegelaste häiritud hingeelu ja välimuse kohta. Kolmandas loos pealkirjaga „Niidukressid” sõidab Ellinor puhkusele lesbilise proua Liibeoni mõisa, kus teda ootab lauljatar Lilli. Sportides ja lõbutsedes tõrjuvad nad Liibeoni pealetükkivaid lähenemiskatseid ja põgenevad lõpuks. Novellis „Entsian” suvitab Ellinor Vahemere ääres - ujub, päevitab, loeb, vestleb ja tantsib. Temasse armub Lübecki poeet Siemsen,

${ }^{2}$ Entusiasmikultuuril ja uuel elutundel või -laadil peatub Semper varemgi, muuhulgas essees „Lüürik ja meie aeg” (1912), kus ta räägib uuest inimesest ning „ergumast” ajavaimust (Semper 1977: 5). Lisaks Gide'ile (kellest Semper kirjutas magistritöö, vt Semper 1929) ja Verhaerenile seostab ta entusiasmikultuuri Walt Whitmani loominguga (Semper 1929: 35).

${ }^{3}$ Tiit Hennoste nimetab Semperit spordivihkajaks (Hennoste 2016: 298). Ma ei nõustu sellega, sest oma tekstides andis Semper spordile pigem positiivse tähenduse, hurjutades ainult noorte liigset sportimist, mis varjutab kõik teised ja eelkõige kultuurilised huvid (Semper 1928, 1969: 164).

${ }^{4}$ Sellega erineb Ellinor eesti kirjanduse vahest tuntuimast nn ideaalnaisest, J. Randvere Ruthist („Ruth”, 1909). Tiina Kirss rõhutab, et Ruth on tekstis küll kõigiti välja joonistatud, kuid ta ei lausu ise sõnakestki, olles vaikiv, justkui kõnevõimetu (Kirss 2006: 71-72). 
keda Ellinor õhutab aktiivsemale elule. Naine päästab mehe nii uppumissurmast kui ka kukkumisest. Viimases ja pikimas jutus „Karukollad” vestleb haritud inimeste seltskond kaasaja päevakajalistel teemadel (soosuhted, eugeenika, üliinimene, tehnika areng), mida Ellinor analüüsib pigem üleolevalt. Tegevust kannab Ellinori soov muuta eluvõõras teadlane Tuppmann elavaloomuliseks inimeseks.

Novellikogu telg on peategelase sirgumine tüdrukust naiseks, mistõttu võib „Ellinori” vaadelda naisminajutustaja arenguloona. Ellinori ambitsioonid ja eluvaated tulevad kõige kujundlikumalt esile esimeses kahes loos, hiljem annab ta pigem hinnanguid teistele tegelastele, jättes oma soovid ja motiivid analüüsita. Tegelase kujunemisloos otsingulisest õpilasest eneseküllaseks, liikuvaks ja analüütiliseks naiseks torkavad silma novellide lillenimedega pealkirjad. ${ }^{5}$ Lisaks sellele, et lilled pakuvad novellidele teatava värvigamma, kannavad nad ka vastuolulisi tähendusi: peale traditsioonilise ilu, naiselikkuse ning hapruse (karikakar, niidukressid) on nad ka sõjakoleduste, kõdunemise ja tühjade loosungite (astrid), surma (entsian) ning pettumuse, häbi ja klammerdumise (karukollad) sümbolid.

\section{„Ellinori” retseptsioonist}

Novellikogu „Ellinor” vastuvõttu iseloomustab usk realismi kui „tõepärasesse” loomelaadi ning kindel arusaam eesti rahvuskirjandusest. Arvustustes tulevad esile kaks keskset probleemi: esiteks, mil määral on „Ellinor” originaalne teos ja mil määral väliskirjanduse järeleaimamine, ning teiseks, kuidas peaks „küpses” tekstis suhestuma sisu ja vorm. Kriitikud kiidavad Semperi laia silmaringi ning vaimukat sõnastust, aga puudu jäävat kandvast ideest, elamusterohkusest (Kärner 1928: 445; Sillaots 1928). Jaan Kärneri sõnutsi on „Ellinori” tegelaste elamused tühised (Kärner 1928: 445).

Marta Sillaots kirjeldab Ellinori äärmiselt ekstsentrilise, omalaadilise, impulsiivse, isemeelse ja ekstravagantsena (viimast sõna kasutab ka Kärner) ning rõhutab novellikogu uuenduslikkust: peategelase omadusi ja hoiakuid iseloomustatakse ainult kaudselt, selle abil, kuidas teised tegelased teda kõnetavad ja temaga käituvad (Sillaots 1928: 51). Viimane ei pea küll päriselt paika, sest mitmetes tekstikohtades avanevad peategelase enda vaated, tema ambitsioonid ja väärtushinnangud. Võib-olla viitab Sillaots nn neutraalse tegelaskirjelduse puudumisele: Ellinori päritolu, välimust ega haridust ei avata üksikasjalikult, neist saab aimu vaid tekstis leiduvatest vihjetest.

Ka Albert Kivikas peatub „Ellinori” vaatepunktil, tähendades, et see on „haiglusesse kalduv” (Kivikas 1928a). Küllap peab ta silmas seda, mida on Ellinori meelest vaja kajastada ja analüüsida ning mida mitte. Teised kriitikud ei ole novellide vaatepunkti hindamisel nii radikaalsed, ehkki nad märkavad jutustamisviisi erilaadsust ja uudsust tollases eesti kirjanduses. Kivikas heidab Semperile ette liigset Euroopa kirjanduse mõju, millega ta jätkab Noor-Eesti aegadest alanud poleemikat (Kivikas 1928a). ${ }^{6}$ Bernhard Linde, kes

\footnotetext{
${ }^{5}$ Lilli ja naisi on seotud eelkõige Lääne-Euroopa dekadentsis. Lill peegeldab XIX sajandi lõpu ja XX sajandi alguse kultuuritekstides naise hinge ning on ühtlasi naistele omaseks peetud ihade ja püüdluste sümbol (Dijkstra 1986: 15).

${ }^{6}$ Kivika ründavale arvamusele kirjutab Semper ka vastulause (vt Semper 1928). Kivikas süüdistas Semperit prantsuse kirjasõna (eriti Paul Morand’i) imiteerimises ning läänelike 
vastupidiselt Kivikale peab prantsuse kirjanduse mõju Semperi loomingus loomulikuks ja peenekoelisekski, nendib siiski, et Semperi intellektuaalne looming jääb tihti kuivaks ja mõistatuslikuks (Linde 1928: 388-390).

Tolleaegsed arvustajad ei peatu aga kehalisusel ja spordil, vaadates mööda ka minategelase enesemääratlusest naisena, kel on „sportlanna keha ja hing” (Semper 1927: 105). ${ }^{7}$ Ometi on just kehalisus ja sport see, mis kerkib esile igast novellist ning seob eri lood. „Niidukressides” ujutakse ja mängitakse tennist, „Entsianis” ujutakse ja sõidetakse süstaga, novellis „Karukollad” uisutatakse ning suusatatakse. Mainitakse spordiga seotud kohti ja tähendusi: „Karikakras” kõneleb Ellinor kaugus- ja kõrgushüppest, „Astrites” nimetatakse rohtu kasvanud staadione, „Entsianis” mõtleb Ellinor Rootsi gümnastikast. „Entsianis" nimetatakse ka tollast kuulsat tennisisti Suzanne Lengleni ning kõikides novellides pööratakse teravdatud tähelepanu kehadele, sh žestidele ja liikumisele. Kui Semperi hilisemate romaanide naisekujud üksnes räägivad/mõtlevad spordist ning nende harrastusi kujutatakse kaude (mina)jutustaja silme läbi ${ }^{9}$ siis „Ellinoris” tegeldakse konkreetsete spordialadega. Dünaamilisust lisavad ka „Ellinori” sõnavara ja tekstikulg: tihti esinevad sõnad „hüppama”, „akrobaatika”, „gümnastika”, „musklid”, samuti personifitseeritud metafoorid („klaveri huuled”, lk 103; „semafori käsi”, lk 56; „suusatav päike”, lk 153) ning kärmelt vahelduvad tegevused ja mõttekäigud (peategelane mainib mitmel pool gide'ilikult, ${ }^{10}$ et haub ärasõitu või tahab ära minna, nt lk 55, 171).

Eelöeldust johtuvalt küsingi: millega seda kõike põhjendada? Kuidas konstrueeritakse keha mina-vaatepunktist ja kuidas see haakub tollase kultuurisituatsiooniga?

\section{Keha ja sport XX sajandi alguse Euroopas: täisväärtusliku elu otsingud}

Johannes Semperi Ellinor usub, et igapäevane keha eest hoolitsemine muudab vaimu nõtkeks ja meele optimistlikuks. Tema huvi aktiivse elustiili, spordi ning keha ja vaimu dualismi (või selle lammutamise) vastu ei ole XX sajandi alguse Euroopas sugugi haruldane. Kultuuriuurija Tim Armstrongi sõnul on kehateema lääne modernsuses lausa kesksel kohal (Armstrong 2005: 65). See

teemade, tegelaskujude (aktiivne sportlik naine) ja stiili matkimises (Kivikas 1928a, 1928b). Semper kukutab need arvamused, väites irooniliselt, et hoopis prantslased on tema tekste kopeerinud (Semper 1928), ja viidates ka oma varasemale novellikogule „Hiina kett” (1918), kus juba ammu enne Kivika mainitud tekste tuhises sportlik naistegelane - suusatav ja uisutav rootslanna Uta (nt Semper 1918: 106-107).

${ }^{7}$ Järgnevates „Ellinori” tekstinäidetes märgin ära ainult leheküljenumbri.

${ }^{8}$ Pehr Henrik Lingi (1776-1839) väljatöötatud võimlemistehnika, mis peegeldab „Rootsi rahva kehalisi, hingelisi ja sotsiaalseid iseäraldusi” (Idla 1928). Eesti tollase tunnustatud võimlemispedagoogi Ernst Idla sõnutsi mõjutas Rootsi kehalise hariduse süsteem ka Eesti kehalise kasvatuse õpetajaid.

${ }^{9}$ Näitena võib tuua romaani „Armukadedus” kangelanna Krista, kelle kohta peategelane Enn sedastab, et ta võimleb hommikuti (Semper 1934a: 161), ning romaani „Kivi kivi peale” Reeda, kelle spordiharrastus tervislikel põhjustel keelatakse ning naine möönab kahetsusega, et on talvel vähe suusatanud, ning kardab, et arst keelab ka kevadised tennisemängud (Semper 1947: 34).

${ }^{10}$ Oma magistritöös „André Gide’i stiili struktuur” (1929) toob Semper ära Gide’i tegelaste kinnisidee olla pidevalt liikumises, vahetada asupaikasid ja reisida, mida Semper nimetab rändamismotiiviks (Semper 1929: 22). 
torkab silma näiteks teaduslik-filosoofilistes arengutes, kunstnike elustiilides ja manifestides ning ka kehakultuuri propageerivates rahvusideoloogiates. Seda illustreerib kehakeskse filosoofia võidukäik (eelkõige Nietzsche ja Bergson), Thomas Hardy, Henrik Ibseni, Walt Whitmani jt teoste kehaga seotud teemad ning näiteks Dorothy Richardsoni tasakaaluka toortoidu propageerimine, rääkimata Harlemi renessansi suurkuju Jean Toomeri kulturismiharrastusest (Armstrong 2005: 65-66). Kehateema jõuline ilmumine kultuuritekstidesse tõukub XIX sajandil alanud intellektuaalsetest ja tunnetuslikest murrangutest, mis seadsid dualistliku inimesekäsituse kahtluse alla ning pöörasid varasemast märgatavalt enam tähelepanu keha eest hoolitsemisele (Armstrong 2005: 65; Hillmann, Maude 2015: 7). Murrangute käivitajateks olid teiste hulgas näiteks Arthur Schopenhauer, kes olemisele ja tahtele keskendudes vastandus kartesiaanlikule ratsionaalsusele ning lääne kultuuris kinnistunud keha ja vaimu dualismile (Armstrong 2005: 65), ning Charles Darwin, kelle „Liikide teke” (1859) rõhutas tervise ja hea füüsilise vormi olulisust liigi püsimise seisukohalt (Childs 2008: 46-47). Keha kui mõiste aktuaalseks muutumine tekitas vajaduse kehaga argisel tasandil teadlikumalt suhestuda. Töötati välja uusi kehakujundusvõtteid (võimlemine, nudism, toortoitumine, paastumine jne) ning mõeldi ka vaimu ja isiksuse dünaamiliseks muutmise võimalustele (Armstrong 2005: 66-67).

Niisugust elustiili uuenduse vajalikkust kuulutabki Semperi „Ellinor”. Irooniliselt vaadeldakse novellis „Karukollad” ka XX sajandi alguse Eesti kultuuriruumis populaarset darvinistlikku eugeenikat, ${ }^{11}$ opetust pärilikest omadustest ja nende parandamisest. Samas kannab kõikide „Ellinori” novellide üldist kehaideaali - sitke, terve, liikuv - usk võimalusse inimest parandada. Niisugused kehaideed on sõnastanud Henri Bergson, Friedrich Nietzsche ja Sigmund Freud, kes olid teedrajavad selliste arusaamade lammutajatena nagu inimmõistuse autonoomia, eksistentsi eesmärgipärasus ning keha teisejärgulisus.

„Ellinori” peategelase tegevusi juhib nimelt rõõm, optimism, soov elada täisväärtuslikku ja intensiivset elu igas hetkes, mis ongi viide Bergsoni ja Nietzsche filosoofiale. Ent Semperi „Ellinor” ja selle peategelase erakordselt energiline elustiil juhinduvad muuhulgas XIX-XX sajandi vahetusel levinud energetismi teooriast, mille rajaja oli baltisaksa päritolu keemik ja Nobeli laureaat Wilhelm Ostwald (Tamm 2016: 31; Undusk 2013: 147). ${ }^{12}$ Niisiis põimuvad Ellinori kujus tollal moodsad teaduslik-filosoofilised mõttesuunad, mis vaatasid elu läbi energia, kiiruse, tahtejõu ja optimismi prisma, soovides kehataju ja -tehnikaid uuendada.

Üks olulisemaid keha ümberkorraldamise mooduseid modernses lääne ühiskonnas oli sport. Kaudselt seostub spordi ja tervisliku elustiili osatähtsus tollases kultuuris Esimese maailmasõja mõjudega. Nimelt suunasid paljud Euroopa, Põhja-Ameerika ja Aasia riigid pärast sõja tohutuid inimkaotusi tähelepanu rahva füüsilisele vormile ja arendasid tervise parandamise ideid

\footnotetext{
${ }^{11}$ Eesti kirjanikest on seda - kõnekeeli tõuteemat - käsitlenud näiteks Villem GrünthalRidala ja Johannes Aavik (Karjahärm 1993; Semper 1971: 138).

${ }^{12}$ Selle teooria järgi on kõik ilmas, sh kultuurinähtused, energia, selle edasikandumine ja võitlus selle pärast. Energetism oli XX sajandi alguses arvestatava levikuga mõtlemisviis, mille rajaja Ostwald sidus muuseas ka inimese „edukuse” - s.o elutöö mahu ja eri valdkondade saavutused - vaba energia ärakasutamise oskusega (Undusk 2013: 157). Teiste hulgas mõjutas see teooria Friedebert Tuglast (Undusk 2009: 556-559).
} 
(Jensen 2013: 3). Nii USA-s, Suurbritannias, Prantsusmaal kui ka futurismist vallatud Itaalias levis saleda ja sportliku keha ideaal (Gori 2012: 167). Eestiski ei olnud futurism tundmatu - Johannes Semper oli üks esimesi, kes tutvustas siinsetele lugejatele seda suundumust, selle dünaamikalembust ja vilkuse kultust (Hennoste 2016: 324-325). Sarnased hoiakud levisid ka spordilembeses Weimari vabariigis ${ }^{13}$ kus vormis keha saavutamine ja hoidmine oli kodanike jaoks pea kohustuslik, sest iga keha esindas sümboolselt rahvust. Nii loodi Saksamaal riigi rahastatavaid terviseprogramme, reformiti perekonda ja seksuaalsust puudutavaid seadusi ning populaarseks said eugeenika, nudism, taimetoitlus ja karskusliikumine (Jensen 2013: 4). ${ }^{14}$ 1919. aastal nõuti ajalehes Illustrierte Sport rahvuse kui keha tervendamist, kusjuures eeskujuks ei seatud mitte tervise-, vaid võistlussportlased ning seda nii meestele kui juba ka naistele (Jensen 2013: 4). See tähendab, et Weimari vabariigis ja mujal Euroopas oli sportimine soovituslik nii meestele kui ka naistele. Enamgi: XX sajandi alguse naisliikumises on märgata täiesti uusi keha ja spordiga seonduvaid ideid, mis lahknesid XIX sajandil ja veel XX sajandi alguse lääne kultuuris levinud koduse, haiglase ja õrna naise ideaalist.

Teisalt tasub meeles pidada, et naiste ligipääs sportimisvõimalustele ei olnud XX sajandi alguses iseenesestmõistetav. Seda enam, et domineerinud hoiakute kohaselt oli sitke ja täiesti terve naine ebaloomulik (Dijkstra 1986: 28-29). Selline naiselikkuse ideoloogia oli iseäranis visa kaduma katoliiklikes kultuurides. Näiteks väitis hispaania kultuurikriitik ja arst Gregorio Marañón essees „Sugu ja töö”, et sport on meeste pärusmaa: vallalised naised võivad hetkeks selles küll edu saavutada, kuid „feminiinne” naine ei tohiks sportida (Marañón 1924: 340). Ka 1920. aastate Itaalias püsis samaaegselt liberaalsemate seisukohtadega katoliiklik hoiak, mille kohaselt sport segas naise pühendumist olulisimale, s.o emarollile (Martin 2011: 78). Need konservatiivsed seisukohad tõukuvad ilmselt Maarja-kultusest, mis seostas naiselikkust emaduse, puhtuse ja õrnusega. Teised Euroopa riigid olid neis küsimustes mitmeti edumeelsemad, kuigi naisemantsipatsiooni, sh naissporti suhtuti valdavalt ikkagi halvakspanuga.

Tänapäevane kehalisuse uurimine on mitmeti seotud naiste võrdõiguslikkuse liikumisega, sest see on tõstnud keha tõsiseltvõetavaks uurimisobjektiks ja sotsiaalpoliitiliselt tähenduslikuks teemaks (Turner 2012: 6). XIX sajandi lõpus ja XX sajandi alguses võitlesid naiste keha vabastamise eest eelkõige lääne keskklassi „uued naised”, kes rääkisid naiste sotsiaalsetest, poliitilistest ja majanduslikest õigustest. „Uute naiste” kehalist enesemääramisõigust on uurimustes sageli seostatud järglaste saamise ja seksuaalsusega, kuid sel juhul on tagaplaanile jäetud tollaste naiste soov end aktiivselt liigutada. Koduperenaise rolli küsimärgi alla seadev ja alternatiivseid enesemääratlemisviise otsiv „uus naine” vajas uute rollidega kohanemiseks teistlaadset energiat, välimust-riietust ja sitkemat füüsist. Silmanähtava muutuse naiste välimusse ja riietusse tõid korsetist loobumine ja reformkleidi tulek (Ots 2006: 19, 22). Sajandialguse sale, poisilik ja sportlik naisetüüp muutus sõdadevahelises

${ }^{13}$ Kuna Semper elas aastatel 1921-1925 Berliinis ning 1926-1927 Pariisis, oli ta ümbritsetud ja küllap (implitsiitselt) teadlik läänelikest kehatehnikatest ja -ideoloogiatest.

${ }^{14}$ Eesti eugeenika selts Tõutervis asutati 1924. aastal. Eugeenikaga oli tihedalt seotud ka karskusliikumine, nimelt pidasid rahvusmeelsed eestlased oluliseks omariikluse ja populatsiooni püsimise nimel hoiduda alkoholist (Kalling 2013: 49, 51). 
Euroopas peavooluks, mis tähendab, et sportlik naine võis, aga ei pruukinud 1920. aastatel tingimata olla võitlev feminist.

Ent kuidas tulid eelmainitud ideed ja praktikad esile Eestis? XX sajandi alguse Eestis olid hoiakud „uute naiste” ja naiste sportimise suhtes vastandlikud. Sõdadevahelisel perioodil domineeris siin rahvuslik-konservatiivne sooideoloogia, millele Semperi „Ellinor” vastandub. Eesti 1920. aastate ajakirjanduses seostati naisliikumist eelkõige moeuuendustega, kuid sisulised küsimused jäid tagaplaanile (Kivimaa 2009: 70). Veel 1927. aastal tekitas poleemikat naiste kõrghariduse omandamise idee ja selle sobimatus harjumuspäraselt olulisima ehk emarolliga (Kirss 2011: 43). Naisemantsipatsiooni seostati enamasti traditsiooniliselt naiselikustatud valdkondadega ning emantsipeerumise võimalusena pakuti välja eelkõige isikliku sfääriga (koduga) seotud rollide muutmist elukutseks (nt kodumajapidamine) (Poska-Grünthal 1936: 91-92). See omakorda võimaldas rakendada naiste identiteedi rahvusliku ideoloogia teenistusse (Kivimaa 2009: 71). „Naisküsimust” käsitleti ka rahvastikupoliitikas: eesti eugeenikud eesotsas Juhan Luigaga nägid naiste „loomulike instinktide" nõrgenemises ja naisliikumises ohtu eestlaste tulevikule (Kalling 2013: 65). „Naiselik” naine oli valitseva mõttelaadi kohaselt pigem rahvuslikult meelestatud ema kui emantsipeerunud sportlane.

See aga ei tähenda, et eesti naised ei otsinud teistsuguseid olemisviise ega sportinud. Üks eesti esimesi kõrgharidusega võimlemisõpetajaid oli naine: 1915. aastal Helsingi ülikooli lõpetanud Anna Raudkats, kes õpetas muuhulgas ujumist. Viimane oli eestlaste hulgas kursuste arvu ja harrastusvõimaluste järgi otsustades populaarne. Ujumisvõistlustel - tollase nimega ujumispidudel - suplesid mehed ja naised koos (Lell 2013: 11). Esimesed eesti naissportlased, kes pääsesid 1936. aastal olümpiamängudele, olid traditsiooniliselt naiselikud iluuisutajad. Tollal tuntud Ilse Hesse ja Veera Nõmmik olid mitmekordsed Eesti meistrid tennises (vt nt Peterson, Lasn 1940: 18-19, 50). See tähendab, et väike hulk eesti naisi olid spordis tegevad, ehkki pigem naiselikuks peetud aladel.

Järgnevalt vaatlen kolme novelli Semperi „Ellinorist”. Milliseid tähendusi omistatakse sportivale naisekehale ning kuivõrd on need kehad naisemantsipatsiooni teenistuses?

\section{Kehani jõudmine novellis „Karikakar”}

„Ellinori” avanovell „Karikakar” on kui sissejuhatus Ellinori kehalisusse ning liikumine keha/mõistuse dihhotoomia lammutamise suunas. Varateismeline Ellinor selgitab oma arusaamu elust, mida ta seostab eelkõige armastuse ja ihaga. ${ }^{15}$ Ta ütleb esmalt, et on tüdinud konventsioonidest (reveranssidest, vormiriietusest) ja rahulikust elust, ${ }^{16}$ ning naudib eelaimust, et „midagi suurt” läheneb. Samal ajal ei saa ta eluga kontakti, sest tema siseilma kammitseb

\footnotetext{
${ }^{15}$ Hiljem täieneb see arusaamaga elust kui avantüürist, seiklusest. Ellinori väärtused sarnanevad Gide'i tegelaste omadega: „väljakippumistung kitsast maailmast”, irdumine „rahulikust sadamast” (vt Semper 1929: 20).

${ }^{16}$ Tollases eesti kirjanduses on sarnasteks naistegelasteks veel Ellu Romeldi Reed Morni „Andekas parasiidis” (1927) ja Lea Ring Betti Alveri „Tuulearmukeses” (1927), varasemast perioodist otsivad uusi, vabamaid olemisvorme näiteks Marta Sillaotsa naistegelased, sh nimitegelane „Anna Holmis” (1913) (Kirss 2006: 84, vt veel Hinrikus 2015: 177-178).
} 
vorm, kest. Tema igatsusedki jäävad saavutamata, sest nende „käed”, nagu Ellinor neid kujutleb, „ei osanud veel kustki kinni haarata” (lk 9). Korraliku õpilasena oskab ta küll kõiki loodusseadusi loetleda (oluline on siin verb, mis ei viita nähtuste mõistmisele), kuid ta ei saa aru iseendast. Novelli kannab seega vabaks saamise soov ja nietzschelik iha „elule ligemale pääseda” (lk 9).

Seda soovi on aga keeruline täita, sest Ellinor ei taju end terviklikuna. Ta adub oma keha muutumist: „Kuid hing elas kes-teab kus, teispool seinu, teises maailmajaos" (lk 10). Vabadust ihalevatele väljaütlemistele lisab naine, et ta vajab kedagi endale suunda näitama, oma „liigutusi mõtestama” (lk 10), mis viitab tema eneseanalüüsi raskustele. Ellinor sõnastab oma ootusi ähmaselt (kas häbelikkuse või oskamatuse tõttu), järgides siiski ajastule omaseid võtteid elujanu, intiimsuhete ja seksuaalsete tungide väljendamiseks.

Vihjamisi selgub, et tammide purunemine, paisude murdumine, rongide kokkupõrge ja õidepuhkemine viitavad seksuaalenergia vallandumisele, ning ihasid, mille kaudu defineeritakse elu, kujutatakse jõulise liikumise, langemise ja tõusmise metafooridega. Tegemist on tavalise naise suguküpsuse saabumise kirjeldusega, kus põimuvad huvi ja kihk, samuti hirm ja oma keha vääritimõistmine (lk 11). Seega on „Karikakra” esimeses pooles kujutatud keha ja mõistust eraldi toimivaina ning keha juhib mõistust. Näiteks kirjeldab Ellinor esimest suudlust nelja huule juhusliku kohtamisena (lk 11), ${ }^{17}$ mis välistab suudlemise tahtlikkuse. Taustaks sellele võib muuhulgas pidada Darwini postulaati teadvusest kui ühest keha funktsioonist, mitte inimeksistentsi keskmest (Hillmann, Maude 2015: 7). Ulrika Maude tõlgendabki kehade kummalise, justkui kontrollimatu tegutsemise kujutamist XIX lõpu ja XX sajandi alguse ilukirjanduses darvinistliku neuroloogiahuvi kaudu, uurides, mil määral on mina sõltumatu ja teadvus kontrollitav ning kuivõrd vabad me tegelikult oma keha juhtimisel oleme (Maude 2015: 200). Sellele vaatenurgale pakuvad lisandusi Ellinori sedastused keha ja hinge lahknevuse kohta ning hirm oma keha kui omatahtsi tegutseja ees. Sama probleem kerkib esile ka novellis „Karukollad”, kus Ellinor tõdeb, et küsib tihti hoopis midagi muud, kui oli planeerinud, ning tellib muud, kui oli otsustanud (lk 138-139). Ilmselgelt on tegemist vihjega freudistlikule teadvustamatuse rollile otsustamisprotsessis.

Novellis „Karikakar” on olulisel kohal kaks unenägu. Ühes üritavad oksad „kui suured mehekäed” takistada Ellinori jõudmist järve äärde (lk 12). Pääsenud siiski vette, märkab ta oma keha justkui esimest korda ning adub, et teda on „nii ehmatavalt palju, et ma kõike ei suutnud enam koos hoida” (lk 12). Ellinorile näib tema keha mitmesena, fragmentidest koosnevana, muuhulgas paljunemisvõimelisena. Ühelt poolt näitab järve jõudmine Ellinori võimet ületada takistusi, kuid teiselt poolt kinnitavad unenäos leiduvad sümbolid ja tegevused lääne kultuuriloos levinud arusaama naisest kui piiritust, voolavast ja ebamäärasest, seega analüüsivõimetust olendist ${ }^{18}$ (Cranny-Francis jt 2003: 2; Hinrikus 2003: 13). Samuti seostub järve minemise kujund, ja eriti eeltoodud

${ }^{17}$ Selline stseen, milles dramaatiline suudlus toimub justkui tegelaste tahtest sõltumatult, leiab aset ka Semperi romaanis „Armukadedus” (Semper 1934a: 84).

${ }^{18}$ Samal ajal omistab Ellinor säärased „naiselikud”, s.o ebamäärased jooned ka proua Liibeoni mehele Mehikule, kes elab pagendatult ärklitoas ja mängib „omaette viiulit, tundide-pikkust viisi, millel polnud algust, otsa ega selgroogu" (lk 65). Niisiis on siin ilmseid osutusi soosuhete ja -rollide tähenduste kõikumisele modernsuse kontekstis. Vormitust seostab Semper naiselikkusega ka oma „Päevaraamatutes” (Semper 2013: 43). 
tammide purunemine, freudistlikus diskursuses levinud tungimetafooridega, mis viitavad irratsionaalsuse ja emotsioonide vallapääsemisele (Frosh 2003: 122). Ent erinevalt Freudi patsientidest, kes pelgasid ihade paljastamist, kartes ühiskondlikku hukkamõistu, on Ellinoril tammide murdumise üle hea meel ja ta usub, et sedasi jõuab ta täielikuma olemiskogemuseni.

Hiljem, ühel suveõhtul, sünnibki „see” (lk 14). Rongis ulatab kaassõitjast noormees Ellinorile karikakrakimbu, mis paneb naise tundma maailma avanemist. Kui mees rongist väljub ja kaob, tunneb Ellinor, et on „kaotanud kõik” (lk 16). Ellinor hüppab intensiivse tundepalangu ajel rongist välja ja püüab meeleheitlikult meest leida. Kohtumist meenutavad esemed muutuvad kirjeldustes personifitseerituks ja kehalikuks: lillekimbust saab piimanäljas imik, lillevartesse salvestub mehe soojus. Sellest kohtumisest sündinud tundetulv ja Ellinori „andumisvalmis” igatsus on feministlik, sest rõhutab naise iha olemasolu ja selle väljendamisvabadust ning mõtestab keha naudingupaigana (lk 21). Ihaleva Ellinori jaoks muutub looduski meheks: „Öö võiks mind siis meeleheites võtta ja üksik täht mind vägistada” (lk 21-22). Novelli nappuse tõttu ei selgu, mida Ellinor tegelikult ootas, kas „see” oli igavese armastuse ja pere (millele viitab lillede muutumine imikuks) või kire maandamise lootus. Novellikogu edasine käik annab alust uskuda viimast.

Juhtunust (mida Ellinor nimetab umbmääraselt „selleks”) väsinud Ellinor uinub aasal. See pilt - noor naine (ehk nümf) looduses magamas - on XIX sajandi lõpu ja XX sajandi alguse kunstis üsna levinud. Kuid Semperi loos muutub see kujund paroodiaks: Ellinor ärkab hommikul märgade jalgadega ning lillekimbu on ära söönud lambad, kes toibuvat naist hirmuga jõllitavad. Eelmise õhtu tundepalangust on alles vaid karikakra - tüdrukute armastusennustuse lille - kollane nutt, mis hakkab Ellinorile sümboliseerima ühiskondlikest normidest vabanemist ja ülesaamist jäägitust („selle”, st armastatu, ihaldatu, pereelu jms) ootamisest.

Ellinori üleolekut saadab tema energilis-sportlik elustiil, mida kujutavad reljeefselt kogu kolmas ja neljas novell.

\section{„Uued naised” tenniseväljakul}

Novellides joonistub selgelt välja peategelase areng: „Karikakras” on naise mina ja keha lahus, ent alates kolmandast loost kujutatakse teda oma kehast teadliku ja seda nautivana, kellele sport pakub võimalust elust mõnu tunda, hetke nautida ja letargiat vältida.

Novellis „Entsian” tuleb lõunamaal puhkav Ellinor ujumast ja läheb hotelli, kust kuuldub muusikat. Ta hiilib klaverimängija selja taha, vaatab teda pikalt salaja ja jätab meelde detailid. Tegemist on mehelikustatud pilgudünaamika ümberpööramisega, sest lääne kultuuritekstides on vaatajaks ja hindajaks olnud tavapäraselt mees, kes teeb naisest oma esteetilis-erootilise objekti (Mulvey 2003: 195; Parente-Čapková 2014: 120). Ellinori pilk, mis paigutab objektipositsiooni mehe, rõhutab naise isepäisust ja julgust. Klaverit mängivat poeeti Siemseni kujutab Ellinor ara ja alandlikuna, „truu penina” (lk 106), ning ta mõtiskleb, et eluvõõral ja emotsionaalsel poeedil võiks ehk abi olla Rootsi gümnastikast ja sügavast hingamisest (lk 117).

Hotellist vee äärde suundudes kohtuvad Ellinor ja Siemsen teiste suvitajatega, sealhulgas Klaudiaga, kelle ärritamiseks ja oma sõltumatuse mani- 
festeerimiseks teeb Ellinor koos Siemseniga järgmist: „...kasvatasin tiritammi, lõin hundiratast, painutasin selja looka, panin jalad kaela taha ja tõusin üles, asetasin poeedi küürutama ja tegin ta üle hüppeid, sundides ka Siemseni seda tegema. Sellest veel vähe, ma panin poeedi pää pääl seisma, ise ta jalust kinni hoides, sundisin teda mustlas-maadlust proovima, mille ta häbenemisest kaotas. // Nõnda kuumutet ja väsitet Siemseni võtsin käsivarrest ja talutasin ta vette.” (Lk 108) „Naiselikku” poeeti kujutatakse siin tüüpiliselt saamatu ja eluvõõrana, mis on kooskõlas tollaste kindlaks kujunenud, n-ö feminiinseid mehi tauninud sooarusaamadega (Kivimaa 2009: 62). Samal ajal on Ellinorile omistatud otsustusvõimelise ja tegutsemisalti subjekti tunnusjooned. Mida vähem Siemsen oma keha tunneb - ta ei taju lõhnasid, ei märka kive teel, ei suuda süstas tasakaalu hoida ning häbeneb liigutamist (lk 109) -, seda enam kontrollib oma keha Ellinor. Naise sitkus ja musklite töö on Semperi tekstis positiivselt tähistatud ning Ellinori kehaline tunnetus peegeldab naisemantsipatsiooni sihte: unistust vabamast, energilisemast ja sportlikumast elustiilist ehk täisväärtuslikumast olemisest. ${ }^{19}$ Aktiivne elustiil haakub tihti isegi enese võimete proovilepanekuga, mitte pelgalt tervisliku liigutamisega (lk 109). Kuid teised tegelased (ei tohi muidugi unustada, et nende hinnanguid tõlgendab minajutustaja), eelkõige Klaudia, suhtuvad Ellinori pigem etteheitvalt ja kadedusega. See omakorda osutab, et säärast lustlikku käitumist avalikus ruumis ei peetud konservatiivsete hoiakute kohaselt naisele sobilikuks. Ellinor ise aga usub, et on eluga vahetumas kontaktis kui kade Klaudia, „raamatutark” Siemsen või novellis „Karukollad” tegutsev Tuppman, kes kõik on pinges, abitud või kohmakad. Nii on novellikogu kahekordselt murranguline: esiteks väljendab see usku külluslikumasse ja hetke väärtustavasse ellu ning teiseks kannab aktiivsusideid naine, keda on traditsiooniliselt peetud passiivseks, vagaks ja koduseks.

Nii maa peal kui ka vees (ujumises, tennises, süstasõidus, maadluses, akrobaatikas, kõrgus- ja kaugushüppes, uisutamises, suusatamises jne) oskusliku „uue naise” Ellinori sportlikkust kirjeldatakse pigem tõsiselt, irooniavabalt. See tähendab, et Ellinori nn maskuliinsed omadused, k.a tema sportlikkus, ei pälvi tekstis etteheiteid erinevalt paljudest XX sajandi alguse kultuuritekstidest, mis rajanesid tollaste autoriteetide, nt Darwini, Spenceri, Weiningeri, Freudi ja Zola seisukohtadel, et meeste aktiivsuse ja naiste passiivsuse kao või nende omaduste segunemisega kaasneb ühiskondliku harmoonia allakäik ja hukk (Dijkstra 1986: 157). Ent konservatiivsed normid on aktuaalsed teise „maskuliinse” naise, „Niidukressidest” pärit lesbilise proua Liibeoni kujutamisviisides. Proua Liibeon peab maamõisa, kuhu ta palub algaja kunstimetseenina (millisesse rolli Ellinor suhtub skeptiliselt) külla noori naiskunstnikke. Liibeoni mõisas suvitav lauljatar Lilli kutsub maale ka Ellinori, kes analüüsib seal Liibeoni kaht poolust - n-ö mehelikku ja naiselikku. Pea kogu info proua kohta saab lugeja Ellinori sõnadest, ehkki teiste tegelaste käitumisest, nt Lilli eemalehoidmisest ja proua mehe vaiksest allumisest, nähtub „meheliku” naise kartus.

${ }^{19}$ Kindlasti oli sportlik elustiil üks „uue naise” võimalusi elada täisväärtuslikku elu, kuid see ei tähistanud tingimata tema võrdõiguslikkuse taotlusi. Seda märkab ka Semper, arvustades Rudolf Sirge kogu „Väikesed soovid” (1935). Semper tähendab halvustavalt: „Mehelik sporditar taltsutab tal viimaks leitnandist naisteküti ning mõlemad asuvad lõpuks Candide’i eeskujul „oma aeda harima”. Naisi lastakse rahulduda sellega, et nad ükskõik mil teel endale lapsed saavad või ka ainult tubli mehe." (Semper 1971: 180) 
Novellis tegeletakse ohtrasti spordiga. Kui „Entsianis” harrastab Ellinor koos Siemseniga meelelahutuslikku spontaanset sporti (süstasõit, ujumine, liival müramine), siis novellis „Niidukressid” mängitakse tennist, mida tollal esitati näiteks Saksa ajakirjanduses kui seksuaalselt ja majanduslikult sõltumatute naiste ala ning mis oli üldse juba tollal Euroopas äärmiselt populaarne (Jensen 2013: 16). „Entsianiski” (lk 113) mainitud tennisist Suzanne Lenglen oli naisõigusluse sümbol. Nais- ja meestennisistide tollased kuvandid kaasasid omadusi, mida traditsiooniliselt naiselikuks või mehelikuks ei peeta: valdavalt kujutati meestennisiste nõrkade, edevate, frivoolsete, dändilikena; naistennisiste aga näidati ülimalt keskendunute, jõuliste ja võistlushimulistena (Jensen 2013: 19, 36). Eestis seostati tennist kui baltisakslaste hulgas populaarset mängu jõukuse ja edukusega - tenniseklubidega liitusid koguni spordikauged inimesed (Ulman jt 2013: 33).

Semperi „tennisjalgne” Ellinor (lk 105) mängibki tennist tehniliselt meisterlikult. Ta üritab võita domineerivat proua Liibeoni: „Küll katsusin teda igapidi väsitada, lõin palli pahemasse nurka, kui ta paremas viibis, ette, kui ta tagapool seisis, ja taha, kui ta võrgu ligidal oli. Ta jooksis raskete kontsade välkudes ja sügavaid jälgi jättes ning kui ma tõrelesin, tõmbas saapad otsast ja küttis paljajalu. [---] Ei aidanud mu seletused mõõdet ja tempereerit mängust: ta vehkis endiselt reketiga kui kurnikepiga." (Lk 73) Sellisest kirjeldusest aimub nn uue naise mitmekülgne figuur. Sportiv ja võiduhimuline Ellinor säilitab mängides siiski „naiseliku” graatsilisuse ning kõiki tegevusi harrastab ta veatult ja nõtkelt. Samal ajal „uus naine” Liibeon spordib kohmakalt ja robustselt - tema tegutsemine on edasi antud negatiivselt. Mõlemad naised on küll kahtlemata „uued”, nii tehniline ja kiire Ellinor kui ka lahmiv ja suur Liibeon, kuid erineval moel.

Ellinori kuju ainulaadsus seisneb tema lahterdamatuses: ta ei sobitu ühessegi modernsesse kujutamisvormi. Femme enfant'i jaoks on ta liialt analüütiline (ehkki lapsnaisega ühendaks teda justkui mänguhimu ja spontaansus) ja vähe „emalik”, femme fragile’i jaoks liialt terve, tugev, rõõsa ja liikuv ning hukatusliku femme fatale'i jaoks liialt vähe meestest huvitatud ning lõbusoptimistlik. Ka ei ole ta XX sajandi alguse loomingulise muusakuju tüüpi (Kivimaa 2006: 224). Sellest johtuvalt muutub mõistetavamaks Sillaotsa ja Kärneri pakutud Ellinori iseloomustus, millel peatusin sissejuhatuses - ta on kahtlemata „omalaadiline” tegelane (Sillaots 1928: 51), st muretu ja rõõmus „uus naine”. Seevastu Liibeoni kui lesbilise günanderi ${ }^{20}$ kujusse koonduvad irooniliselt ühiskondlikud hirmud, mille tõid kaasa naisemantsipatsioon ja eelkõige homoseksuaalsus.

„Uue naise” vastased kartsid nimelt võimuhierarhiate lagunemisega seoses traditsioonilise peremudeli kadumist ning naiste mehelikustumist. Proua Liibeonisse on humoorikas-irooniliselt üle kantud kõik need pelgused: spordialadest armastab Liibeon jõudu nõudvaid, agressiivsemaid, näiteks kurni ja jahti, „naiselikku” tennist ta põlastab; toidust eelistab liha, jälestades maiuseid, ning ta kannab meesteriideid. Oma abikaasa on naine pagendanud pööningule, mistõttu on mees muutunud sotsiaalselt ebakindlaks ning ei tee asja ka spordiväljakule, kus domineerivad amatsoonid - see sõna tähistab essees „Prantsuse vaim” tugevate lihastega sportlannasid (Semper 1934b: 160) ehk

${ }^{20}$ 1891. aastal ilmus prantslase Joséphin Péladani romaan „Günander”, kus ta määratles androgüüni kui noort ja feminiinset meest ning talle vastanduvat negatiivset günanderit kui maskuliinset naist, kes tähistas mandumist (Dijkstra 1986: 273). 
siinkirjutaja arvates „uusi naisi”. Ehkki meheriiete kandmist ja välimuse maskuliinseks kujundamist võib tõesti pidada naisemantsipatsiooni märgiks (Kivimaa 2009: 91), tühistab Liibeoni tõsiseltvõetavuse Ellinori irooniline toon, samuti Lilli ning Liibeoni abikaasa hirm naise ees.

Semper kõneleb homoseksuaalsusest oma 1929. aasta uurimuses André Gide’ist, kus ta põhjendab seda „inversiooni” range kasvatuse ning liigse kiindumisega emasse (Semper 1929: 8, 22, 36). Homoseksuaalsus on modernismile huvipakkuv teema. Esimest korda kasutas seda terminit ungarlane Karl Maria Kertenby aastal 1869. Homoseksuaalsust mõisteti XIX sajandi keskpaigast alates kartesiaanlikult kui ebakõla keha ja hinge vahel. Teise tollase levinud hoiaku kohaselt peeti homoseksuaalsuse põhjuseks probleemi reaalsuse tajumisega, mis kallutab fantaasiatesse, lõhkudes niimoodi sidemed igapäevaeluga (Laanes 2016: 161).

XIX sajandi lõpu seksuaalsuse uurijad ei rääkinud aga naiste omavahelistest intiimsuhetest, sest naisi ei seostatud seksuaalse enesemääratlemisega ning naisekehade peamise funktsioonina nähti naudingu asemel laste saamist (Bauer 2015: 103-104). XX sajandi alguskümnenditeks - mil ilmus ka „Ellinor” - kõneldi naistevahelisest ihast juba avameelsemalt, ehkki nii homokui ka heteroseksuaalsete aktide selge kujutamine oli jätkuvalt tabu. Seetõttu keelati näiteks nii lesbilist armastust kujutava Radclyffe Halli romaani „Üksinduse kaev” („The Well of Loneliness”, 1928) kui ka D. H. Lawrence’i romaani „Leedi Chatterley armuke” („Lady Chatterley's Lover”, 1928) avaldamine (Bauer 2015: 110-115). Semperi „Niidukressid” käsitleb niisiis tollal Euroopas aktuaalset teemat, mis Eestis, kus selget homoainestikku kirjanduses veel ei kohta, kannab radikaalset tähendust. Samal ajal ei astu „Ellinor” üle kindlate piiride, sest naise iha naiste vastu saab külge iroonilise märgi: Liibeoni võrgutuskatsete alguses on juba aimata, et need ei jõua konkreetsete aktideni. Konservatiivsest hoiakust lähtuvalt ei ole homoseksuaalne Liibeon „Ellinoris” seksuaalset küllastumust otsiv vaba ja tegus naine, vaid ta näitlikustab kartesiaanlikku keha ja hinge vahelist ebakõla, st Liibeoni naisekehas pesitseb „mehelik” hing, mis põhjendab ka naise himu teiste naiste ja mitte meeste järele.

Seega kuulutab „Niidukressid” vabamat naissubjektsust ainult teatud piirini: androgüünsuse ideaali kandev „amatsoon” Ellinor on iseseisev, kuid ei imiteeri mingil moel füüsilist mehelikkust, ta säilitab liigutades, kõneldes, riietudes naiseliku graatsia, nõtkuse ja erootilise veetlevuse. Ellinor on mehepilgu jaoks positiivne „uus naine”, vastupidiselt eemaletõukavalt kujutatud Liibeonile kui günanderile. Seda vastandust rõhutab eriti Liibeoni ja Ellinori suhestumine veespordiga.

\section{Vee vormiv kutse}

Ellinor naudib (spontaanseid) kehalisi tegevusi, millest mitmed leiavad aset vees (ujumine, süstasõit). Naisolendi seotus veega ei ole XIX sajandi lõpu ja XX sajandi alguse kultuuris võõras teema: kujutavas kunstis esitati lisaks suplevatele naistele kaht peamist veest pärit naisfiguuri, passiivset kaldale uhutud undiini ning hävingut külvavat aktiivset sireeni (Dijkstra 1986: 258).

Ellinor astub novellis „Karikakar” unenäos külma vette ja jälgib seal oma keha distantsilt, novellis „Niidukressid” meelitab järv Ellinori alasti suplusele 
ning „Entsian” algab peategelase veest väljumisega. Vesi (passiivne, piiritu, hukutav) on eriti kujutavas kunstis traditsiooniliselt naiselikkuse sümbol (Dijkstra 1986: 265) ning see seletab ka Ellinori veelembust ja proua Liibeoni jonnakat kaldal istumist. Mehelik Liibeon ei lähe teiste naistega ujuma, vaid ta sõuab paadis või suitsetab veepiiril ujujaid jälgides. Ellinor täheldab, et kui Liibeon siiski ujub, mida novellis küll ei juhtu, siis alati kõhuli, mitte selili, nagu ta üldse armastab liikuda püsti asendis, tajudes endas „vertikaalseid tunge" (lk 76). See on jällegi proua otsene vastuhakk sellisele naiselikkusele, mis seostub lebamise, igavlemise ja mitte midagi tegemisega. Nõnda vastandub Liibeon nii sõnades kui ka tegudes traditsioonilisele naiselikule õrnusele ja passiivsusele. Ellinor mõtiskleb sooga seotud tähenduste üle, võttes naiselikkuse ja mehelikkuse piinlikult täpselt tükkideks ja asetades need teineteisega vastuollu, vaadeldes sooperspektiivist nii harrastusi, toite, värve, riietust, isikuomadusi kui ka žeste (lk 74-75). Ilmselgelt lähtub tema arutluskäik traditsioonilisest heteronormatiivsest soosüsteemist. Ellinor küsib küll retooriliselt, „miks peaks inimesi paigutetama ainult kahte leeri, nad on ju palju mitmekesisemad" (lk 79), kuid radikaalse vabadusnõude tühistavad läbivalt kahetised kommentaarid, mis naeruvääristavad lesbilise Liibeoni ihasid, pakkumata talle seda valikuvabadust, mida Ellinori küsimus justkui pooldaks. Ka Ellinor ei suhestu veega traditsiooniliselt. Ta üritab jälitava paadi eest ära ujuda ning naudib sukeldumist ja lihaste tööd, mistõttu ta ei sobitu, nagu Liibeongi, kummagi naisolendi kunstis kujutamise tavaga, ei undiini ega sireeniga. See tähendab, et Ellinor naudib lihtsalt sportimist, soovimata kellelegi silmailu pakkuda ega kedagi hukatusse ahvatleda. Veelgi iseseisvamaks muudab aga Ellinori tõik, et sireenid jäid tihti kalurite võrkudesse kinni; ent Ellinor rõhutab, kuidas ta põhjaõngesid järjekindlalt väldib (lk 60) ning vees valvsust ei kaota. Ellinor ujubki lihtsalt mõnu ja treeningu pärast, millel on laiem taust.

Ujumise efektiivsust modernsuse ideaaliks oleva harmoonilise kehakuju saavutamiseks propageeriti Euroopas ja ka Eestis (Gori 2012: 168; Lell 2013: 11). Näiteks Itaalias peetigi ujumist naisele sobivaimaks spordialaks: see vormivat keha ilusaks ja moekaks, „naiselikele” rollidele sobivaks, kusjuures eeskujuks seati põhjamaade ja ameerika harmoonilise kehaga naisujujad (Gori 2012: 168). Sportimine ei tähendanud lihtsalt meeldivat ettevõtmist, vaid konkreetse mõju ja tulemusega, ilusat ja moekat keha taotlevat tegevust. Füüsilise aktiivsuse populaarsusega Euroopas muutus ka sportlaste kehakuju normatiivseks: kitsaste puusade, väikeste rindade ja pingul kehaga naissportlased seati eeskujuks vastandina lopsakate emalike vormidega kehatüübile. 1920 . aastate naised ei soovinudki näida emalike ja viljakatena, sest täisväärtuslik elamine - ujumine, sportimine, tantsimine - ei võimaldanud kehale lopsakust (Gilman 1999: 229-230). Seega kujunes kehamõtestus iseendasse sulguvaks: naised soovisid uut keha, et olla varasemast füüsiliselt aktiivsemad ja manifesteerida võrdõiguslikkust, kuid pidid ühtlasi olema järjepidevalt sportlikud, et seda uut keha hoida. Kehalise vabanemisihaga põimub ka soov meeldida, olla ihaldusväärne, mis jätab ilusat ja saledat keha taotlevad, „loomulike” kvaliteetide ja rangete kontuuridega naised siiski teatud määral patriarhaalsele loogikale alluvateks objektideks.

„Ellinoris” selliseid enesepiiramisi esile ei tule ning kõik Ellinori kehaga seotud tegevused tunduvad spontaansed ja lustlikud, mitte millestki konkreetsest ajendatud, samuti ei kasuta ta oma keha kujundamiseks teadlikke mee- 
todeid, vähemalt ta ei kõnele neist. Samal ajal Ellinori mõtted teiste tegelaste kohta näitavad teadlikkust kehatehnikatest ja nende mõjust loomuliku, tasakaaluka kehaideaali saavutamisele. Näiteks usub Ellinor, et lisaks Siemsenile oleks spordist kasu ka „mehhaanilisele inimesele” Tuppmanile (lk 142). Sama tendents ilmneb Semperi hilisemas loomingus, kus naised väljendavad nii sõnades kui ka tegudes selget arusaama sellest, milline peaks olema kaunis naisekeha.

\section{Kokkuvõte}

Johannes Semperi novellikogu „Ellinor” avab 1920. aastate eesti kirjanduses uuendusliku naisvaatepunkti, samuti lõbusa, sportliku ja kehakeskse kujutamisviisi ning on eriline entusiasmikultuuri, ka homoseksuaalsuse käsitlemise tõttu. Peategelase, energilise „uue naise” keha kujutatakse liikuva, sitke, aktiivse ja nautivana, mis haakub tollaste euroopalike kunsti- ja elukäsitluste ning hoiakute ja praktikatega, osutades muuhulgas nii naisliikumisele, progressiideoloogiale kui ka rahvastikupoliitilistele iseärasustele. Novellidest nähtub usk aktiivsesse ellu ning keha sõltumatus, mis seostub XIX sajandi lõpu ja XX sajandi alguse teadusfilosoofiliste arengutega, eelkõige keha ja vaimu dualismi murenemisega.

Niisiis on see novellikogu katseks sõnastada liikuvat, ent samas väga analüütilist elustiili ja mõtlemisviisi. Peategelase sportimise ja sõnade kaudu nihkub küllust otsiv „uus naine” elule lähemale. Neid mõtteid kannab usk „tõelisemasse-ürgsemasse" olemisse, mida ei paku eluvõõras raamatukultuur. Siiski ei ole naisekeha alati vabanemise teenistuses, novellidest ilmneb, et leidub „naiselikumaid” ja „loomulikumaid” viise keha liigutamiseks, mille tõttu tõuseb kontrastselt esile ka jõuline, „ebanaiselik” ja lesbiline Liibeon, kes on tollases eesti kirjanduses vaieldamatult äärmuslik karakter.

„Ellinor” on ilmekas näide naiselikkuse, seksuaalsuse ja kehalikkuse kontrastsest mõtestamisest XX sajandi alguse Euroopas. Hoolimata oma vastuoludest ja tihti lõikavast irooniast on Semperi novellikogu modernse, vaba ja täisväärtusliku elustiili manifest. Teist säärase rõhuasetusega ilukirjandusteksti on XX sajandi alguse eesti kirjandusest raske leida.

\section{Kirjandus}

Arm strong, Tim 2005. Modernism. A Cultural History. Cambridge: Polity Press. Bauer, Heike 2015. Literary sexualities. - The Cambridge Companion to the Body in Literature. Toim David Hillman, Ulrika Maude. New York: Cambridge University Press, lk 101-115.

Child s, Peter 2008. Modernism. Second Edition. London-New York: Routledge. Cranny-Francis, Anne, Waring, Wendy, Stravropoulos, Pam, Kirkby, Joan 2003. Gender Studies. Terms and Debates. New York: Palgrave Macmillan.

Dijkstra, Bram 1986. Idols of Perversity. Fantasies of Feminine Evil in Fin-desiècle Culture. New York-Oxford: Oxford University Press. 
Frosh, Stephen 2003. Psychoanalysis in Britain: „The Rituals of destruction”. A Concise Companion to Modernism. Toim David Bradshaw. Oxford: Blackwell Publishing, lk 116-137.

Gilm a n, Sander 1999. Making the Body Beautiful: A Cultural History of Aesthetic Surgery. Princeton: Princeton University Press.

Gori, Gigliola 2012. Italian Fascism and the Female Body: Sport, Submissive Women and Strong Mothers. London-New York: Routledge.

Has s elblatt, Cornelius 2016. Värske vein vanas lähkris. - C. Hasselblatt, Eesti kirjanduse ajalugu. Tlk Mari Tarvas, Maris Saagpakk, Ave Mattheus. (Heuremata.) Tallinn-Tartu: Tartu Ülikooli Kirjastus, lk 478-482.

Hennoste, Tiit 2016. Eesti kirjanduslik avangard 20. sajandi algul. Hüpped modernismi poole I. (Heuremata.) Tallinn-Tartu: Tartu Ülikooli Kirjastus.

Hillmann, David, Ma u de, Ulrika 2015. Introduction. - The Cambridge Companion to the Body in Literature. Toim D. Hillmann, U. Maude. New York: Cambridge University Press, lk 1-9.

Hinrikus, Mirjam 2003. Tammsaare „lapsnaised”: A. H. Tammsaare naistegelastest 19. ja 20. sajandi vahetuse kultuurikontekstis. Feministlik vaatenurk. - Haridus, nr 11, lk 12-17.

Hinrikus, Mirjam 2015. Tammsaare's constructions of femininity in light of Weininger's concept of sex difference. - Journal of Baltic Studies, kd 46, nr 2, June 2015, lk 171-197.

I d l a, Ernst 1928. Rootsi võimlemine Eesti kehakasvatusliikumise huvi keskpunktiks. - Eesti Spordileht 14. IX, nr 31.

Jensen, Erik N. 2013. Body by Weimar. Athletes, Gender and German Modernity. New York: Oxford University Press.

Kalling, Ken 2013. The Application of Eugenics in Estonia 1918-1940. - Baltic Eugenics: Bio-Politics, Race and Nation in Interwar Estonia, Latvia and Lithuania 1918-1940. Amsterdam-New York: Rodopi, lk 49-80.

Ka r el s o n, Marit 2015. Kui kirjandus jäi aega kinni: sõjast ja kirjandusest Johannes Semperi loomingus. - Esimene maailmasõda Eesti kultuuris. Koost, toim Mirjam Hinrikus, Ave Mattheus. (Tallinna Ülikooli eesti keele ja kultuuri instituudi toimetised 17.) Tallinn: Tallinna Ülikool, Eesti TA Underi ja Tuglase Kirjanduskeskus, lk 261-283.

Karja här m, Toomas 1993. Tõuküsimus Eestis iseseisvuse eel. Historiograafiline referaat. - Akadeemia, nr 7, lk 1347-1364.

Kirss, Tiina 2006. Ruthi õed: sajandipöörde naiste reaalsus ja fantaasia. J. Randvere „Ruth” 19.-20. sajandi vahetuse kultuuris. Koost Mirjam Hinrikus. Tallinn: Underi ja Tuglase Kirjanduskeskus, lk 71-98.

Kirs s, Tiina 2011. Uus naine ja ENÜSi algaastad. - Eesti Naisüliõpilaste Selts 100. Koost Rutt Hinrikus, T. Kirss. Tartu: ENÜS, lk 35-44.

Kivikas, Albert 1928a. Kolm novellisti. Ülevaade III. August Gailit: „Ristisõitjad”. Johannes Semper: „Sillatalad” ja „Ellinor”. Mihkel Jürna: „Tavalised”. Postimees 6. I, lk 4.

Kivikas, Albert 1928b. Johannes Semperi mõjutajad. Lisandusülevaade III. Postimees 20. I, lk 4-5.

Kivimaa, Katrin 2006. Ruthi tegelaskujust fin-de-siècle’i kunstiideaalide taustal. - J. Randvere „Ruth” 19.-20. sajandi vahetuse kultuuris. Koost Mirjam Hinrikus. Tallinn: Underi ja Tuglase Kirjanduskeskus, lk 215-226.

Kivima a, Katrin 2009. Rahvuslik ja modernne naiselikkus eesti kunstis 1850 2000. Tallinn-Tartu: Tartu Ülikooli Kirjastus. 
Kärner, Jaan 1928. Eesti proosa 1927. - Looming, nr 5, lk 440-447.

La a nes, Eneken 2016. Autobiograafia ja enesekirjutus Rousseau'st Gide'ini. Vikerkaar, nr 1-2, lk 156-164.

Le1l, Daimar 2013. Mees esimesest reast. Anton Õunapuu 125. - Sport ja Muuseum, nr 2, lk 3-17.

Lin de, Bernhard 1928. Mõtiskelud Johannes Semperi „Ellinori” ja „Sillatalade” puhul. - Eesti Kirjandus, nr 7, lk 387-390.

Mar a ñ ón, Gregorio 1924. Sexo y trabajo. - Revista de Occidente, nr 6, lk 305-342.

Martin, Simon 2011. Sport Italia. The Italian Love-Affair with Sport. LondonNew York: I.B. Tauris.

M a u d e, Ulrika 2015. Literature and neurology. - The Cambridge Companion to the Body in Literature. Toim David Hillman, U. Maude. New York: Cambridge University Press, lk 197-213.

Mulvey, Laura 2003. Visuaalne nauding ja narratiivne kino. - Ariadne Lõng, nr $1 / 2$, lk 192-200.

Oles k, Sirje 2002. Tõdede vankuval müüril. Artikleid ajast ja luulest. (EKLA töid kirjandusest ja kultuuriloost 1.) Tartu: Eesti Kirjandusmuuseum.

Ots, Loone 2006. Ruth keset laineid: Randvere Ruthi ümbrus eesti kultuuriruumis. - J. Randvere „Ruth” 19.-20. sajandi vahetuse kultuuris. Koost Mirjam Hinrikus. Tallinn: Underi ja Tuglase Kirjanduskeskus, lk 15-39.

Parente-Čapková, Viola 2014. Decadent New Woman (Un)Bound: Mimetic Strategies in L. Onerva's Mirdja. Turu: University of Turku.

Peter s o n, I., La s n, K. 1940. Tennis. Tartu: Loodus.

Poska-Grünthal, Vera 1936. Naine ja naisliikumine. Peajooni naisliikumise ajaloost ja probleemistikust. Tartu: Eesti Kirjanduse Selts.

Ri ch ard s o n, Niall, L o cks, Adam 2014. Body Studies. The Basics. London-New York: Routledge.

Se m per, Johannes 1914. Entusiasmi kultur. (E. Verhaereni Venemaal viibimise puhuks). - Vaba Sõna, nr 2, lk 74-77.

S e m p er, Johannes 1918. Hiina kett. Tartu: Odamees.

S e m per, Johannes 1927. Ellinor. Tartu: Loodus.

S e m per, Johannes 1928. Järelmärkusi A. Kiwikale. - Postimees 22. I, lk 4.

Semper, Johannes 1929. André Gide'i stiili struktuur. (Akadeemilise Kirjandusühingu toimetised VII.) Tartu: Akadeemilise Kirjandusühingu Kirjastus, http://dspace.ut.ee/bitstream/handle/10062/51450/semper_andre_7_1929_ocr. pdf?sequence=1\&isAllowed=y (19. XII 2016).

Se m per, Johannes 1934a. Armukadedus. Tartu: Noor-Eesti.

Se m per, Johannes 1934b. Prantsuse vaim. Tartu: Noor-Eesti.

S e m p er, Johannes 1947. Kivi kivi peale. Tallinn: Ilukirjandus ja Kunst.

Sem per, Johannes 1969. Mõtterännakuid I. Artikleid ja esseid. Tallinn: Eesti Raamat.

Sem per, Johannes 1971. Mõtterännakuid II. Artikleid ja esseid. Tallinn: Eesti Raamat.

Sem per, Johannes 1977. Mõtterännakuid III. Artikleid ja esseid. Tallinn: Eesti Raamat.

Se m p er, Johannes 2013. Päevaraamatud. Tartu: Ilmamaa.

Silla ots, Marta 1928. Johannes Semper: Ellinor. Novellid. - Eesti Kirjandus, nr 1 , lk 50-51. 
T a m m, Marek 2016. Sissejuhatus. Mis on kultuur ja kultuuriteadused. - Kuidas uurida kultuuri? Kultuuriteaduste metodoloogia. Koost, toim M. Tamm. Tallinn: Tallinna Ülikooli Kirjastus, lk 7-50.

Turner, Bryan S. 2012. Introduction: The turn of the body. - Routledge Handbook of Body Studies. London-New York: Routledge, lk 1-17.

Ulman, Jaak, Jürine, Jaan, Põld oja, Ants, Värv, Maarja 2013. Eesti tennis 100. Tallinn: Best Print.

Und u sk, Jaan (koost) 2009. Friedebert Tuglas, Valik proosat. Kommenteeritud autoriantoloogia. Tallinn: Avita.

Undusk, Jaan 2013. Energiageenius. Wilhelm Ostwaldi eluvaatest. - Teadusmõte Eestis (VIII). Teaduskultuur. Tallinn: Eesti Teaduste Akadeemia, lk 147159 .

\section{The body and soul of a sportswoman as seen in Johannes Semper's short story collection „Ellinor”}

Keywords: Johannes Semper, body studies, sports, New Woman, homosexuality

The article explores the depiction of the body of a sporting woman, especially of one playing tennis or swimming, in Johannes Semper's short story collection „Ellinor” (1927). There are three reasons why „Ellinor” has a radical meaning in the Estonian literature of the time. Firstly, the activities are consistently portrayed through the female point of view; secondly, the stories are permeated by an enthusiastic and luxuriant sense of life, which defies the book culture as remote from life; and thirdly, both a sporting „new woman” and homosexuality were certainly novel subjects in the Estonian culture of the time.

The article analyses the aims and aspirations of „Ellinor's” female protagonist, her active and sporting lifestyle and its connections with the modern social and cultural vibes. Semper's sporting „new woman” has to do with the scientific and philosophical trends of the time, such as energetism, Freudianism and Darwin-based eugenics, while the focus on bodily perceptions bears obvious traces of Nietzsche and Bergson, referring at the same time to certain changes going on in modernising societies (female emancipation, population politics in the interwar period).

Using the key concepts „body”, „sports” and „new woman”, the stories are considered in the cultural context of the time, where femininity would rather refer to the home-making role of a woman, although the importance of physical fitness was also emphasised both as a basis of ethnic survival and the beauty ideal. „Ellinor” is a vivid example of the ambiguous interpretation of the „new femininity”, sexuality and corporeality in the early $20^{\text {th }}$-century European culture. Despite Semper's ambivalence and often scathing irony, especially towards the lesbian character of Liibeon, his Ellinor stories are a remarkably bold manifesto of modern, free and fulfilling lifestyle and attitudes. There is hardly another text of fiction with such emphasis to be found in the early $20^{\text {th }}$-century Estonian literature.

Merlin Kirikal (b. 1986), Tallinn University, doctoral student of Cultural Studies, merlinkirikal@gmail.com 